\title{
Influence of Residential Spatial Position to Trip Generation in Surabaya
}

\author{
Wahju Herijanto. ${ }^{1}$, Indrasurya B. Mochtar ${ }^{2}$, Achmad Wicaksono ${ }^{3}$ \\ Civil Engineering, Institut Teknologi Sepuluh Nopember $(\text { ITS })^{I}$ \\ Civil Engineering, Institut Teknologi Sepuluh Nopember (ITS) ${ }^{2}$ \\ Civil Engineering, Brawijaya University ${ }^{3}$
}

\begin{abstract}
Zonal trip generation is usually assummed to be influenced only by demographic and economic variables. It is seldom to consider spatial position of the zones as an influence variables to its trip generation. In actual condition, people will consider strategic position of residential area when they choose to buy or rent of their home, in accordance with their place of activities such as working, studying for their children and shopping. This research aim is to calculate the influence of spatial position of residential zones from the activities centers to zonal trip generation in Surabaya, Indonesia. Surabaya has several activities centers that can be classified as urban centers and suburban centers. In order to define position of residential zones in relation with activities centers, travel time is defined as a spatial measure which can be measured using Google Maps. Trip generation data is compiled from origin-destination matrix from household interview survey. Regression analysis is used for calculation of the influence of spatial position of residential zones in relation to the activities centres to zonal trip generation. The result shows that travel time to urban center influences reduction of the residential trip generation more than travel time to suburban centers does. However, still many trips were not influenced by travel time from residential to city center since housing ownership in Surabaya is fixed system more than flexible one, and housing at periphery area much cheaper than at city center.
\end{abstract}

Keywords_trip generation, geographical and spatial position, urban centre, suburban centre

\section{INTRODUCTION}

$\mathrm{T}_{\mathrm{t}}$ he development of big city that can be concentrated at a traditional city center or spread at multiple suburban centers will generate trip generation from residential areas. It is common to assume that trip generated from origin zones is influenced by zone population.

This research digging other possibilities of variables that can influence trip generation. Travel time to city center or suburban centers can be analysed as potensial variables as suggested by Dickey (1974) in several cases in US [1].

For this purpose, this research compiles origin destination data that is derived from a household interview survey hold by Transportation Office of Surabaya in 2011.

\section{METHOD}

Household interview survey is held in 2011 with respondent 7000 household, that means level accuracy more than $95 \%$ in accordance of subdivision to 31 subdistrict zoning system. Several origin-destination matrix is compiled from this data, including matrix of trip by modes, trip by purpose, home based and non home based, peak hours, and daily.

Data of population [2] and daily zonal trip production is shown in Table 1, while position of each zone is shown in Picture 1.
Regression analysis is used in analysis the influence of independent variables to the trip production, in this research are population and travel time to city center Travel time to city center is measured using google maps, which presents three option. The fastest path is used in this research.

\section{ANALYSIS}

Regression analysis using population as independent variables and daily trip as dependent variables resulting regression model $\mathrm{Y}=0.5333 \mathrm{X}+42419$ and $\mathrm{R}^{2} 0.3552$, as shown in Figure 2. On the other side, travel time to city center as independent variable resulting reggression model: $\mathrm{Y}=-209 ., 2 \mathrm{X}+146073$ and $\mathrm{R}^{2} 0.1841$ as shown in Figure 3.

Because the result is unsatisfied, a partision of data using geographical position was tried. Zones close city center consist of subdistric Gubeng, Tegalsari, Genteng, Simokerto, Pabean Cantikan, Bubutan and Krembangan is tested and resulting reggression model $\mathrm{Y}=1.0188 \mathrm{X}+$ 7025.3 wth $\mathrm{R}^{2} 0.8079$ as shown in Figure 4. Using the same zones and travel time to city center as independent variable resultung model $\mathrm{Y}=-2164.2 \mathrm{X}-160884$ with $\mathrm{R}^{2} 0.1524$ as shown in Figure 5.

On the other hand a distant zones with rather high proportion of wealthy housing is chosen which includes subdistrics Gayungan, Tenggilis Mejoyo, Gununganyar, Rungkut, Sukolilo, Mulyorejo, Dukuhpakis, Wiyung, Lakarsantri, Sambikerep and Sukomanunggal is tested using population as independent variable and also travel time to city center as well. 
Regional Conference in Civil Engineering (RCCE)

The Third International Conference on Civil Engineering Research (ICCER)

August $1^{\text {st }}-2^{\text {nd }} 2017$, Surabaya - Indonesia

Table 1. Data consist of Population, travel time to city center and number of trip

\begin{tabular}{|c|c|c|c|c|c|}
\hline No & Sub district & Population & $\begin{array}{l}\text { Travel time to center } \\
\text { (minutes) }\end{array}$ & $\begin{array}{l}\text { Total trip } \\
\text { (trip /day) }\end{array}$ & $\begin{array}{l}\text { Trip by car } \\
\text { (Trip/day) }\end{array}$ \\
\hline 1 & Karangpilang & 73100 & 40 & 80581 & 939 \\
\hline 2 & Jambangan & 46200 & 23 & 55064 & 611 \\
\hline 3 & Gayungan & 46900 & 18 & 113105 & 3296 \\
\hline 4 & Wonocolo & 81800 & 21 & 109049 & 310 \\
\hline 5 & Tenggilis Mejoyo & 56800 & 29 & 51338 & 254 \\
\hline 6 & Gunung Anyar & 50300 & 36 & 64188 & 976 \\
\hline 7 & Rungkut & 99900 & 30 & 80458 & 337 \\
\hline 8 & Sukolilo & 104500 & 19 & 119734 & 1323 \\
\hline 9 & Mulyorejo & 82700 & 27 & 103772 & 5056 \\
\hline 10 & Gubeng & 154400 & 9 & 132050 & 1147 \\
\hline 11 & Wonokromo & 184300 & 13 & 45838 & 1782 \\
\hline 12 & Dukuh Pakis & 61100 & 22 & 18378 & 501 \\
\hline 13 & Wiyung & 65000 & 23 & 42250 & 922 \\
\hline 14 & Lakar Santri & 51600 & 40 & 43312 & 325 \\
\hline 15 & Sambi Kerep & 55700 & 41 & 15525 & 91 \\
\hline 16 & Tandes & 95200 & 31 & 152842 & 2248 \\
\hline 17 & Sukomanunggal & 98700 & 25 & 102503 & 1359 \\
\hline 18 & Sawahan & 224100 & 15 & 234004 & 2741 \\
\hline 19 & Tegal Sari & 112200 & 8 & 150903 & 6910 \\
\hline 20 & Genteng & 67900 & 9 & 78667 & 5525 \\
\hline 21 & Tambak Sari & 229800 & 16 & 143076 & 3856 \\
\hline 22 & Kenjeran & 134200 & 27 & 77173 & 1453 \\
\hline 23 & Bulak & 37500 & 31 & 101409 & 807 \\
\hline 24 & Simokerto & 102700 & 21 & 164850 & 5123 \\
\hline 25 & Semampir & 196600 & 25 & 153909 & 11406 \\
\hline 26 & Pabean Cantian & 91500 & 24 & 52268 & 758 \\
\hline 27 & Bubutan & 114900 & 21 & 96284 & 6470 \\
\hline 28 & Krembangan & 123700 & 19 & 89510 & 5641 \\
\hline 29 & Asemrowo & 38800 & 28 & 83010 & 3148 \\
\hline 30 & Benowo & 48700 & 40 & 101021 & 3174 \\
\hline 31 & Pakal & 42900 & 45 & 44723 & 1627 \\
\hline
\end{tabular}

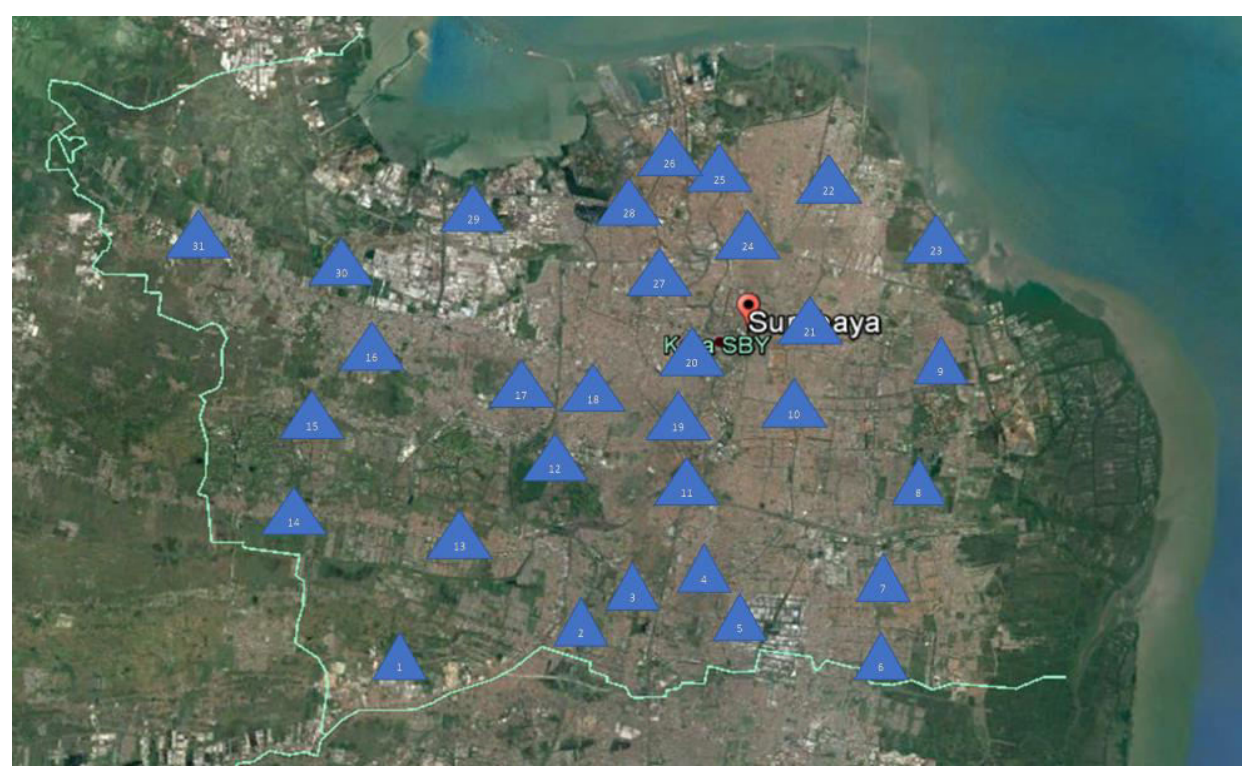

Figure 1. Position of zones based on subdistrict in Surabaya 


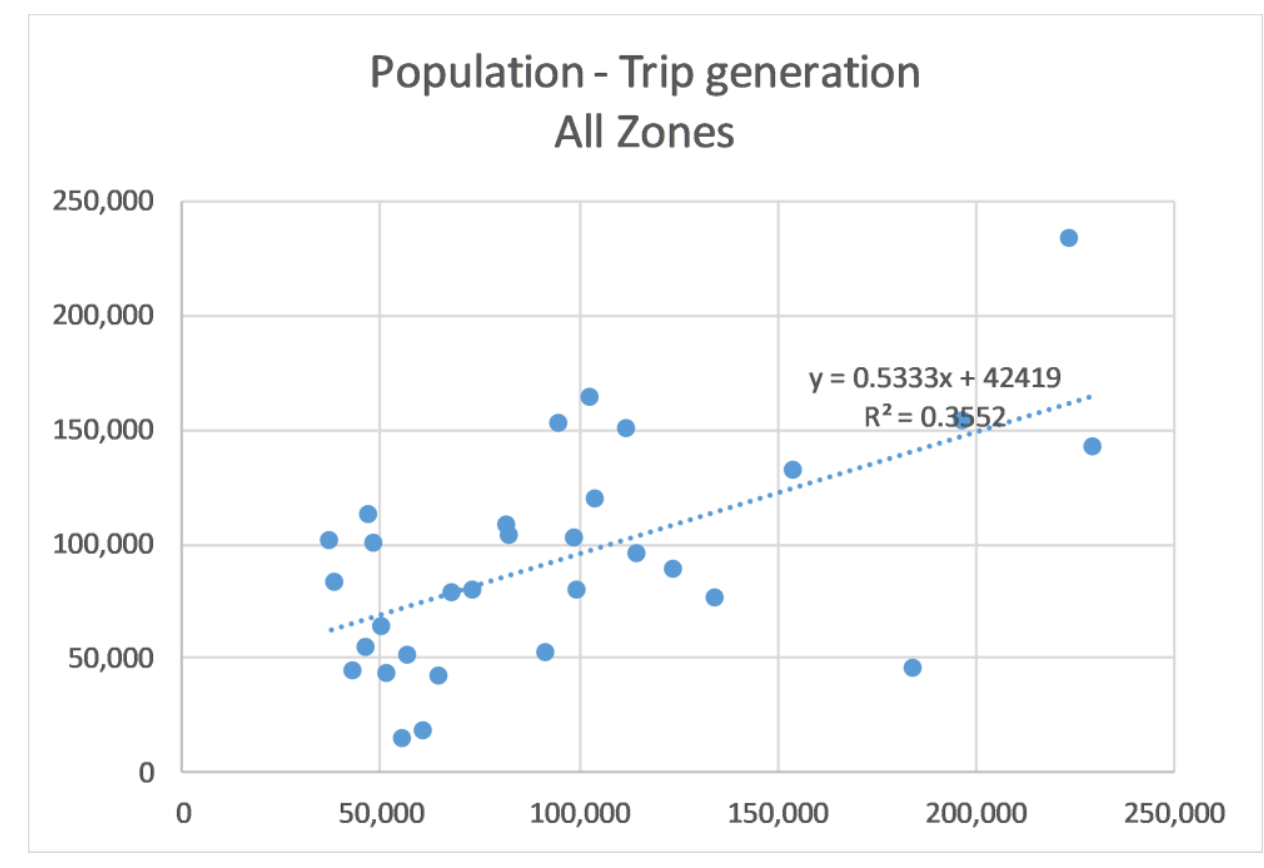

Figure 2. Influence of population to trip production of all zones

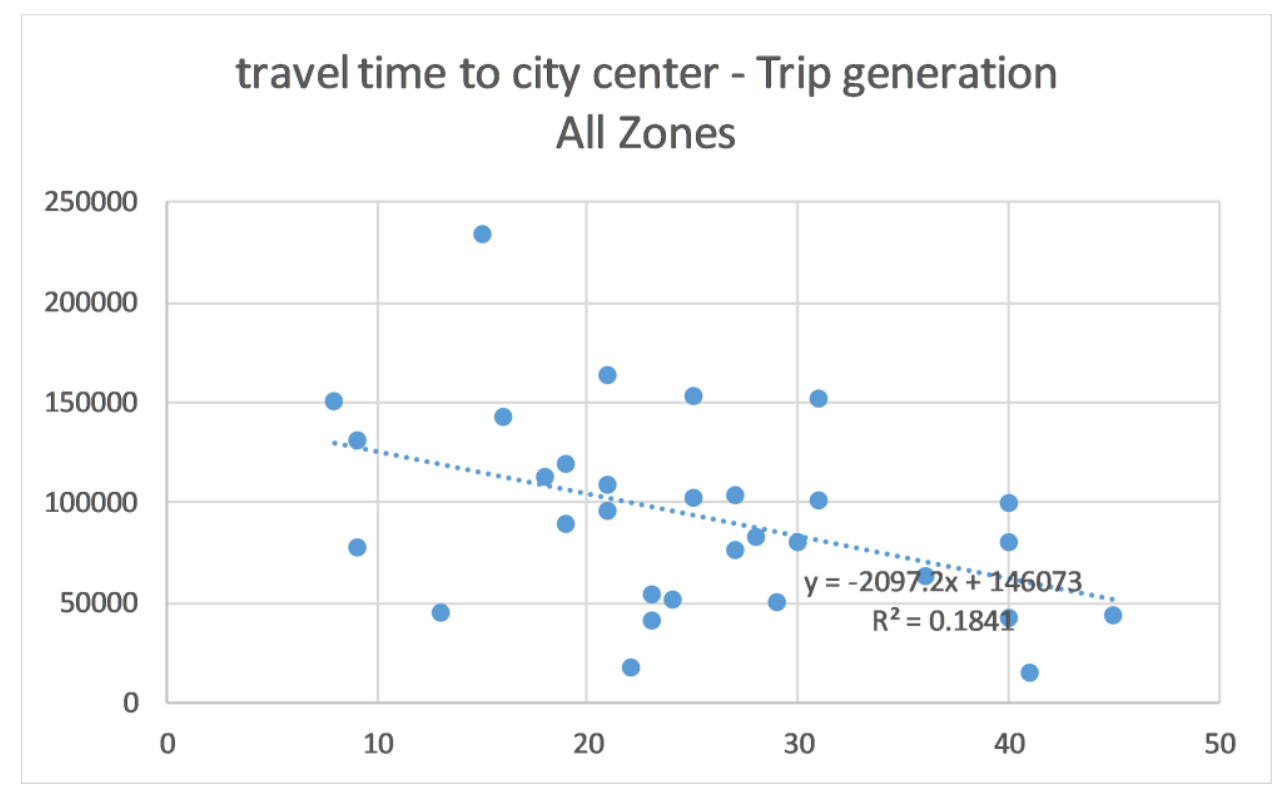

Figure 3. Influence of travel time to trip production of all zones 


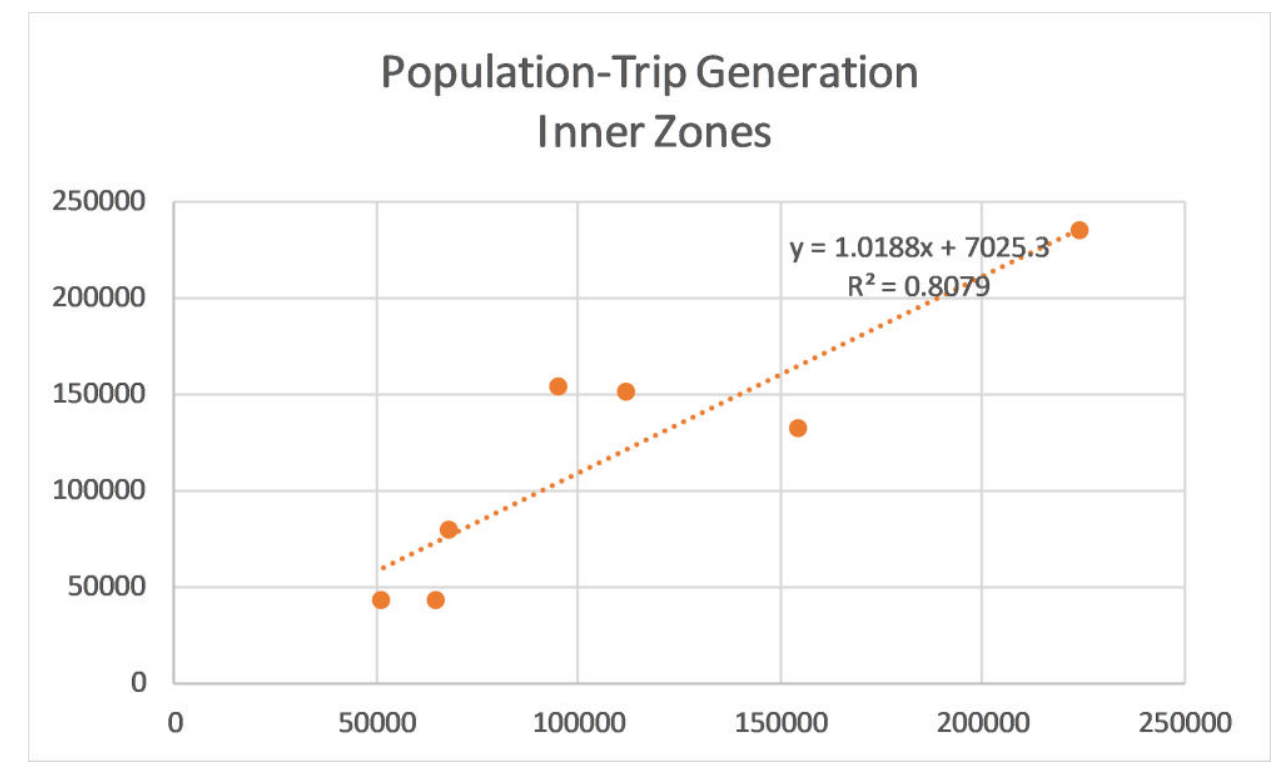

Figure 4. Influence of population to trip production of inner zones

Travel time to city center - trip generation Inner Zones

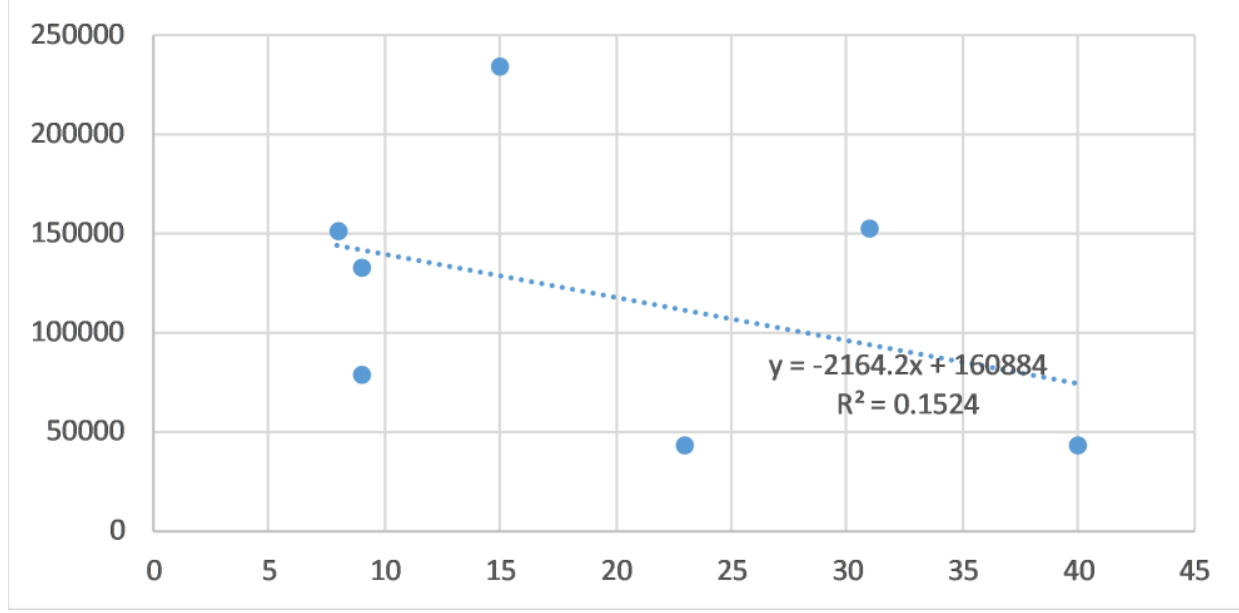




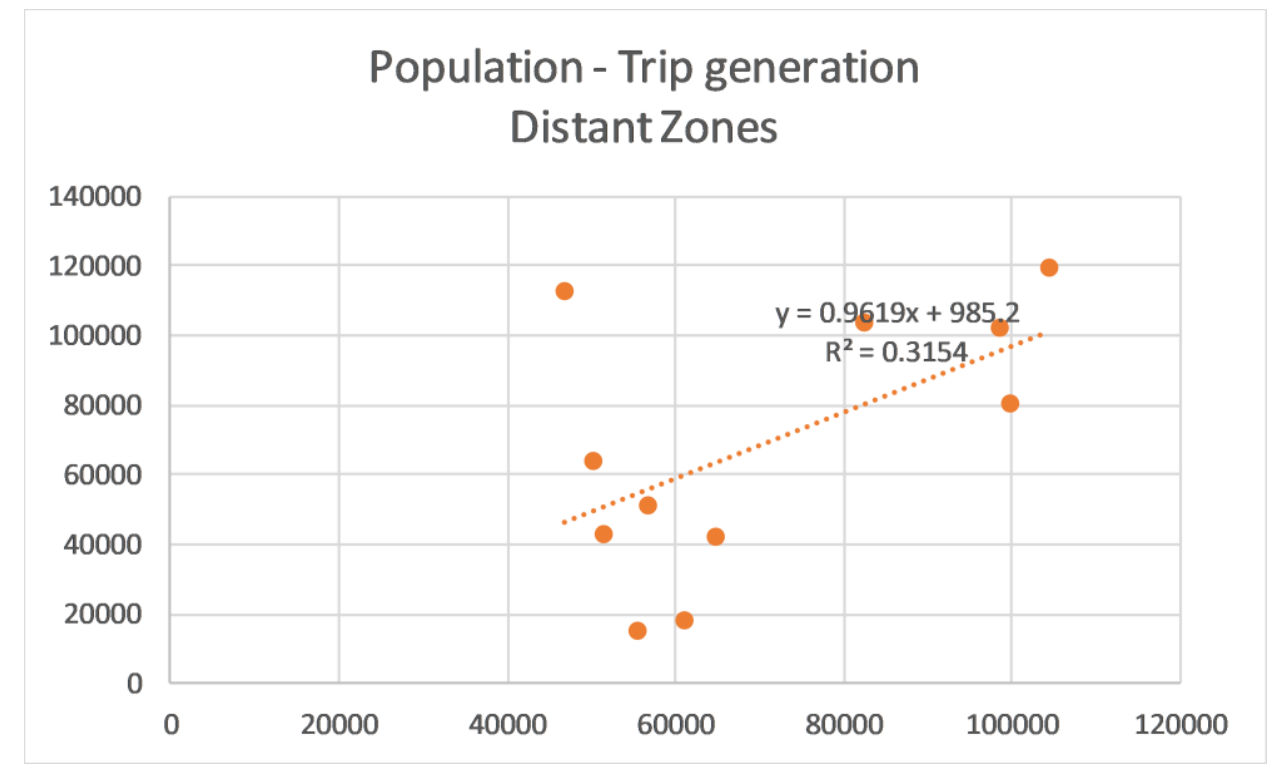

Figure 6. Influence of population to trip production of distant zones

\section{Travel time to city center - Trip generation Distant zones}

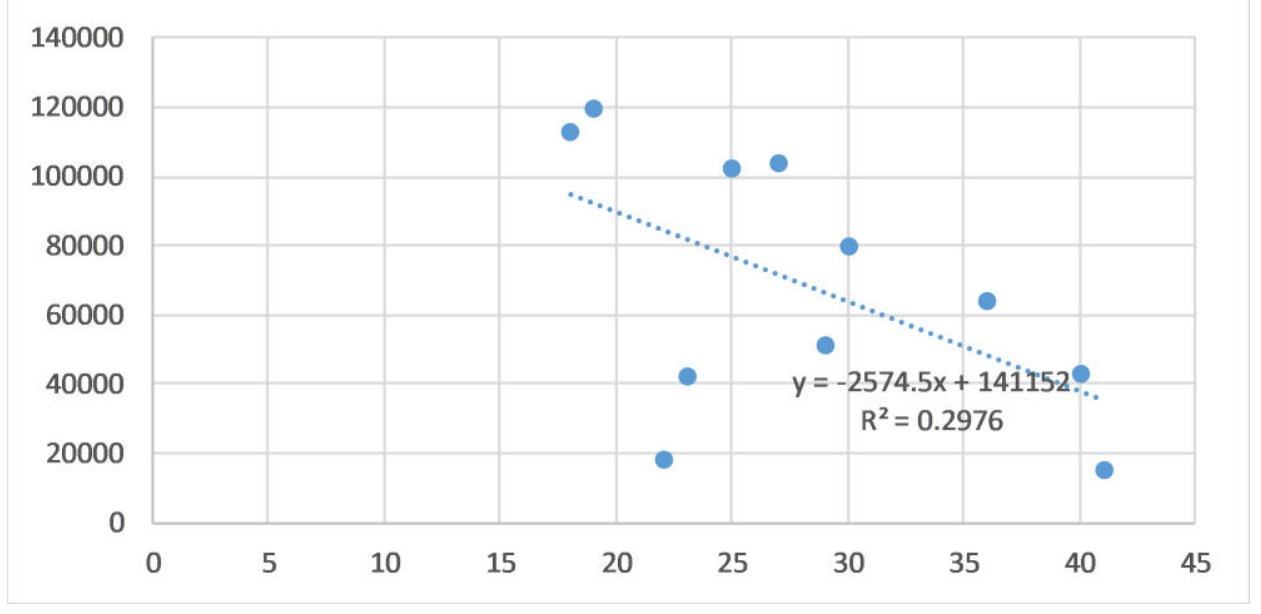


With population as independent variable a formula $\mathrm{Y}=0.9619 \mathrm{X}+985.2$ and $\mathrm{R}^{2} 0.3154$ as shown in Figure 6, While travel time tu city center as independent variable give formula $\mathrm{Y}=-2574.5 \mathrm{X}-141152$ and $\mathrm{R}^{2}$ 0.2976

\section{RESULTS AND DISCUSSION}

For the whole city, reggression model $\mathrm{R}^{2} 0.3552$ and 0.1841 for population and travel time to central respectively. Both are unsatisfied.

For inner city trip, the population and travel time to central give $\mathrm{R}^{2} 0.8079$ and 0.1524 . It is shown that population significantly influencing trip generation.
For trip generation of distant zones,. $\mathrm{R}^{2}$ for population variable is 0.3154 , while travel time to central give $\mathrm{R}^{2} 0.2976$. Therefore influence of travel time to central to trip generation is slightly increase, but it is not significant.

\section{REFERENCES}

[1] J. W. Dickey, Metropolitan Transportation Planning, 2nd ed. Taylor and Francis, 1983.

[2] Government of Surabaya, "Surabaya Dalam Angka," 2011. 